здобувач ступеня $\mathrm{PhD}$ кафедри вікової та педагогічної психології Рівненського державного гуманітарного університету, викладач Сарненського педагогічного коледжу РДГУ http://orcid.org/ 0000-0002-9447-4455

DOI https://doi.org/10.35619/praprv.v1i15.179

\title{
ДОСЛІДЖЕННЯ ОСОБЛИВОСТЕЙ ПСИХОЛОГІЧНИХ ХАРАКТЕРИСТИК У ОСІБ ЮНАЦЬКОГО ВІКУ 3 РІЗНИМ РІВНЕМ ДОВІРИ В МІЖОСОБИСТІСНИХ СТОСУНКАХ
}

\begin{abstract}
Анотація. Стаття присвячена теоретичному обтрунтуванню та емпіричному розгляду проблеми довіри і сочіально-психологічних характеристик у осіб юначького (студентського) віку. Встановлено, щуо рівень емпатії та довіри особистості $i$ міжособистісні стосунки юнаків знаходяться у взаємозв'язку $i$ характеризуються загальною психологічною особливістю: силою прояву емпатії, щзо входять до емоційної сфери особистості, $i$ співвідношенням рівнів міжособистісних стосунків. Завдяки особливостям емпатії та довірливого спілкування юнаки можуть оцінювати навколишніх людей, встановлювати певне значення відносин, які набувають протягом певного періоду часу. Докорінна зміна соціальної ситуачії розвитку викликає інтенсифікацію програм пошуку шляхів особистісної самореалізачії, прийняття відповідальних рішень, перебудови системи зв'язків з оточуючими. Сочіальні норми й правила, засвоєні в попередні вікові періоди, лягають в основу формування власної системи поглядів на реалії співжиття людей в соціумі. На підставі результатів діагностики було виявлено переважну більшість осіб $(85,7 \%)$ з низьким рівнем довіри в міжособистісних стосунках, у яких були досліджені такі сочіально-психологічні характеристики, як типи ставлення до оточуючих $i$ рівень емпатичних здібностей. Результати емпіричного дослідження вказують на залежність особистості у прийнятті рішення довіряти чи ні від думки інших людей, постійний пошук підтвердження правильності свого вибору, невпевненість у власних можливостях. Статистичний аналіз отриманих результатів дозволив виявити достовірні відмінності в стилях (mипах) міжособистісних відносин, рівні розвитку емпатичних здібностей у студентів з низьким рівнем довіри. Отримані результати стали психологічною основою для розробки сочіально-психологічного тренінгу, як ефективного засобу підвищення рівня довіри студентів у період ранньої юності, адже саме довіра виконує сочіальнопсихологічні функиї пізнання, інтерактивності, адаптаціï, інтеграції, орієнтування, регулювання, комунікації, прогнозування, забезпечує розвиток, самовираження ц̆ самовдосконалення.
\end{abstract}

Ключові слова: рання юність, міжособистісні стосунки, довірливі стосунки, довіра, емпатія.

Постановка проблеми. Актуальність проблеми дослідження набуває особливої ваги зважаючи на те, що саме поняття довіри зумовлює якість міжособистісних стосунків, визначає такі поняття, як дружба, симпатія, сумісність, згуртованість, пронизує всі сторони людського життя. Суспільні процеси, що відбуваються в останні роки в нашій країні, суттєво змінили цінності і культурні стереотипи соціально-психологічної взаємодії. 3 одного боку, міжособистісні стосунки 3 іншими людьми передбачають обмін інформацією, думками, переживаннями, а з іншого - розуміння і прийняття один одного. У таких умовах важливого значення набуває довіра, яка виконує функцію зв'язку між суб'єктами спілкування та соціальної взаємодії. Проблема довіри до інших людей постає з особливою гостротою у період ранньої юності, адже саме у цьому віці проходить самовизначення свого місця у світі. 
Аналіз останніх досліджень 3 проблеми. Проблема розвитку довіри до інших людей стала предметом наукового дослідження багатьох учених (Антоненко, Голуб, 2008; Купрейченко, Скрипкіна, Табхарова, 2012).

Аналіз наукової літератури показав, що в міжособистісних стосунках з'ясовано сутність, закономірності та їх вплив на активність особистості. Однак напрямок, пов'язаний із вивченням проблеми довіри в контексті міжособистісних стосунків у період ранньої юності, не здобув у науці достатнього висвітлення, тому наше дослідження спрямоване на виявлення впливу довіри на характер спілкування та взаємовідносин між хлопцями та дівчатами у ранній юності, адже саме цей віковий період є сенситивним для становлення та закріплення ціннісних орієнтацій як стійкої структури особистості, значною мірою визначаючи стосунки людини з навколишнім світом у подальшому дорослому житті.

Мета статті полягає у розкритті результатів емпіричного дослідження довіри у системі міжособистісних стосунків у молодіжних спільнотах.

Виклад основного матеріалу дослідження. Дослідники стверджують, що феномен довіри до інших людей потребує максимальної психологічної близькості у спілкуванні та взаємодії. Особливо у період ранньої юності, коли перед молодою людиною постає гостра потреба побудови ефективного діалогу з іншими людьми. Довіра дозволяє людині активно взаємодіяти з новими людьми, незнайомими та малознайомими суб'єктами соціального середовища. При цьому довіра до інших людей, з одного боку, пов'язана з певним ризиком, а 3 іншого - потребує перевірки досвідом. Тому, виникаючи спочатку у суб'єктивному, внутрішньому світі людини як переживання або певне ставлення, довіра може проявлятися лише в активності людини. Акт соціальної взаємодії слугує перевіркою рівня вияву довіри, i в залежності від попереднього досвіду, постійно коригується людиною.

У вітчизняній психології існує безліч думок з приводу того, яке місце посідають міжособистісні відносини в реальній системі життєдіяльності людини. Перш за все, необхідно згадати про Мясищева (1998), який вважав, «що найголовніше, що визначає особистість - іiі ставлення до людей, що є одночасно взаємовідносинами. Міжособистісні стосунки - це сукупність зв'язків, що складаються між людьми у формі почуттів, суджень та звернень один до одного. Міжособистісні стосунки включають: сприйняття і розуміння людьми один одного; міжособистісну привабливість (тяжіння і симпатія); взаємодію та поведінку» (с.67). Юнацький вік - вік зростання сили Я, його здатності проявити і зберегти свою індивідуальність; у цей час вже $є$ підстави для подолання страху втрати свого Я в умовах групової діяльності. Міжособистісні стосунки в юнацькому віці відіграють значну роль, хоча і відрізняються двома протилежними тенденціями: розширенням сфери (збільшення кількості контактів, розширення меж спілкування), з одного боку, і зростаючою індивідуалізацією, відокремленням, з іншого.

У сучасному світі успіх багатьох процесів у значній мірі залежить від того, які взаємини складаються між людьми, включеними у ці процеси. Не $\epsilon$ винятком і освітній процес у Сарненському педагогічному коледжі РДГУ, адже саме він $є$ підмурівком формування довіри, що зумовлює якість міжособистісної і міжгрупової взаємодії, визначає характер міжособистісних стосунків у період ранньої юності. У цей період молода людина вибирає професію, оволодіває нею, а також переживає процес формування світогляду, ідеалів, переконань. Основою дослідження стало припущення про те, що в юнацькому віці довіра $є$ основою становлення та розвитку міжособистісних стосунків. Об'єктом дослідження виступає довіра як феномен міжособистісних стосунків; предметом - особливості міжособистісних стосунків у осіб юнацького віку з різним рівнем довіри.

Емпіричне дослідження проводилося у 2020 році на базі Сарненського педагогічного коледжу РДГУ. У дослідженні брали участь студенти $1-3$ курсів у віці 15 - 18 років у кількості 160 осіб (140 дівчат та 20 юнаків).

Для встановлення характеру зв'язку рівня розвитку довіри особистості 3 міжособистісними стосунками у період юнацтва нами було обрано такі методики: «Віра в людей» чи «Шкала довіри Маршалла Розенберга»; «Діагностика рівня емпатичних 
здібностей за методикою В.В.Бойко»; «Методика діагностики міжособистісних відносин Т.Лірі».

Дослідження проходило у три етапи. На першому етапі була проведена діагностика рівня довіри в міжособистісних стосунках за допомогою шкали довіри Розенберга, яка оцінює загальну довіру особистості до людей і людської спільноти в цілому.

Аналіз та узагальнення результатів дослідження за методикою шкали довіри Розенберга дозволили визначити наступні показники рівнів довіри студентів періоду ранньої юності до інших людей. Результати дослідження показали, що більшість (86\%) студентів виявляють низький рівень довіри до інших людей. Кількісні результати дослідження відображено у діаграмі (рис. 1).

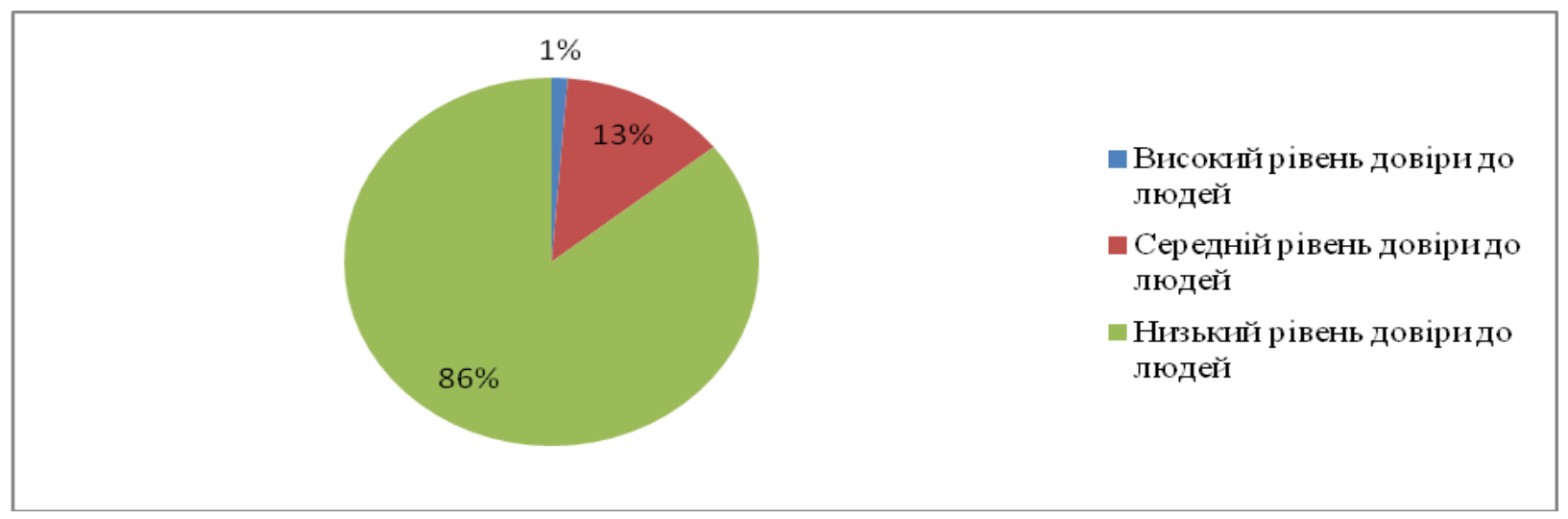

Рис. 1. Рівень довіри до інших людей у період ранньої юності

Середній (13\%) та високий (1\%) рівні довіри до інших людей проявляє незначна частина студентів. Це означає, що в повсякденному житті юнаки та дівчата, з одного боку, прагнуть довіряти людям, а 3 іншого - роблять це нерішуче, продовжуючи остерігатися, боятися невиправданості власної довірливості. Отримані результати вказують на залежність особистості у прийнятті рішення довіряти чи ні від думки інших людей, постійний пошук підтвердження правильності свого вибору, невпевненість у власних можливостях. 3 якою б силою не була спрямована юність на пошук свого місця у світі, як би не була вона інтелектуально готова до осмислення всього сущого, багато чого вона не знає - ще немає досвіду реального практичного і духовного життя серед близьких та інших людей. Саме в юності загострюється потреба до відокремлення, прагнення захистити свій унікальний світ від вторгнення сторонніх і близьких людей для того, щоб через довіру зміцнити міжособистісні стосунки, щоб зберегти свою індивідуальність, реалізувати свої домагання на визнання. Погоджуємося 3 думкою Келлі, який вважав, що «для гармонійної соціальної взаємодії необхідно, щоб одна людина психологічно поставила себе на місце іншої, щоб краще розуміти та прогнозувати ії теперішню й майбутню поведінку» (Хьелл, 2007, с.451).

Виявлення механізмів та характеру зв'язку емпатії та довіри у міжособистісних стосунках розглядається на матеріалі діагностики рівня емпатичних здібностей за методикою Бойко, що стало другим етапом дослідження. Аналіз та узагальнення результатів дослідження за даною методикою представлено у таблиці 2.

Таблиия 2

Показники рівнів розвитку емпатії студентів періоду ранньої юності

\begin{tabular}{|l|c|}
\hline Рівні емпатії & Кількісні показники (у\%) \\
\hline Високий рівень емпатії & 0 \\
\hline Середній рівень емпатії & 12 \\
\hline Занижений рівень емпатії & 71 \\
\hline Дуже низький рівень емпатії & 17 \\
\hline
\end{tabular}


Занижений рівень емпатії (71\%) засвідчує факт недостатньої тї сформованості, невміння проникати у світ почуттів інших. Для юнаків та дівчат не властиво звертати увагу, сприйняття і мислення «на сутність будь-якої іншої людини: іï стан, проблеми, поведінку» (Ильин, 2013, с.455).

Необхідною умовою міжособистісної взаємодії $є$ увага, інтерес, прийняття іншими, особливо близькими, значимими людьми. Мясищев (1998) підкреслював, що «емоційноціннісні і поведінкові параметри формують форми взаємодії. Юність характеризується розширенням кола особистісно значимих стосунків, які завжди емоційно забарвлені (моральні почуття, емпатія, потреба у дружбі та любові, політичні, релігійні почуття)» (с.5) Центральне психологічне новоутворення юнацького віку - встановлення стійкої самосвідомості та стабільного образу «Я». Це пов'язано 3 посиленням особистісного контролю, самоуправлінням, новою стадією розвитку інтелекту. Юнацьке «Я» ще не стабільне, дифузне, підвладне різним впливам. Бажання часто сприймається як дійсне, вигадане - часто як реальне. Психологічне становлення «Я» переживається як нечіткий неспокій, відчуття внутрішньої порожнечі, невизначеного очікування. Звідси - сильне зростання потреби у спілкуванні з одночасним підвищенням вибірковості спілкування, тому що не кожному юнаку можна довірити свій внутрішній світ. Водночас часто проявляється потреба у самотності, бажанні побути наодинці з самим собою. Юнацькому вікові властиве перебільшення особистісної унікальності, але з віком виявляють усе більше відмінностей між собою та «типовим» однолітком. Звідси - напружена потреба у психологічній інтимності, яка допомагає не лише зрозуміти внутрішній світ іншого, а й створити себе самого.

Юнаки та дівчата у періоді ранньої юності залишаються чутливими людьми іронічний погляд яких, влучне слово іншої людини можуть разом знезброїти молоду людину і збити з неї апломб, що так часто демонструється. Лише із завершенням юнацького віку молода людина починає реально опановувати захисні механізми, які не тільки дозволяють їй ззовні захищати себе від стороннього вторгнення, але i зміцнюють іiі внутрішньо. Відокремлення як засіб утримання дистанції при взаємодії з іншими дозволяє молодій людині «зберігати своє обличчя» на емоційному та раціональному рівні спілкування. Саме в юності відбувається сходження людини до найвищого потенціалу людяності і духовності, але саме в цьому віці людина може зануритися до найпохмуріших глибин нелюдськості. Рівень емпатії та довіри особистості і міжособистісні стосунки юнаків знаходяться у взаємозв'язку і характеризуються загальною психологічною особливістю: силою прояву емпатії, що входять до емоційної сфери особистості, i співвідношенням рівнів міжособистісних стосунків. Завдяки особливостям емпатії та довірливого спілкування юнаки можуть оцінювати навколишніх людей, встановлювати певне значення відносин, які набувають протягом певного періоду часу.

Отже, взаємозв'язок особливостей розвитку емпатії особистості та міжособистісних стосунків юнаків безперечно існує. Чим більше особистість вміє співпереживати, ставити себе на місце співрозмовнка, тим легше їй буде встановлювати контакти 3 оточуючими людьми. Вічєв також вважав, що «унаслідок тривалої взаємодії й на основі єдиних інтересів і цілей виникає соціально-психологічна спільність, яка характеризується стійким духовним зв'язком між тими, хто спілкується, взаєморозумінням, згуртованістю та довірою. А довірливість $\epsilon$ специфічною формою емоційно-ціннісного ставлення суб'єкта до іншого як до самого себе, який у своїх оцінках виділяє те, що хотів би отримати суб'єкт довіри» (Хьелл, 2007, с.36).

На третьому етапі дослідження була використана методика діагностики міжособистісних відносин Т.Лірі, що дало змогу виявити соціально-психологічні характеристики у студентів з різним рівнем довіри.

Як засвідчують результати діагностичного дослідження, студенти періоду ранньої юності проявляють такі характерологічні риси, як владність, самовпевненість, нетерпимість, впертість та лагідність, слухняність, несамостійність, безкорисливість у міжособистісних стосунках. 


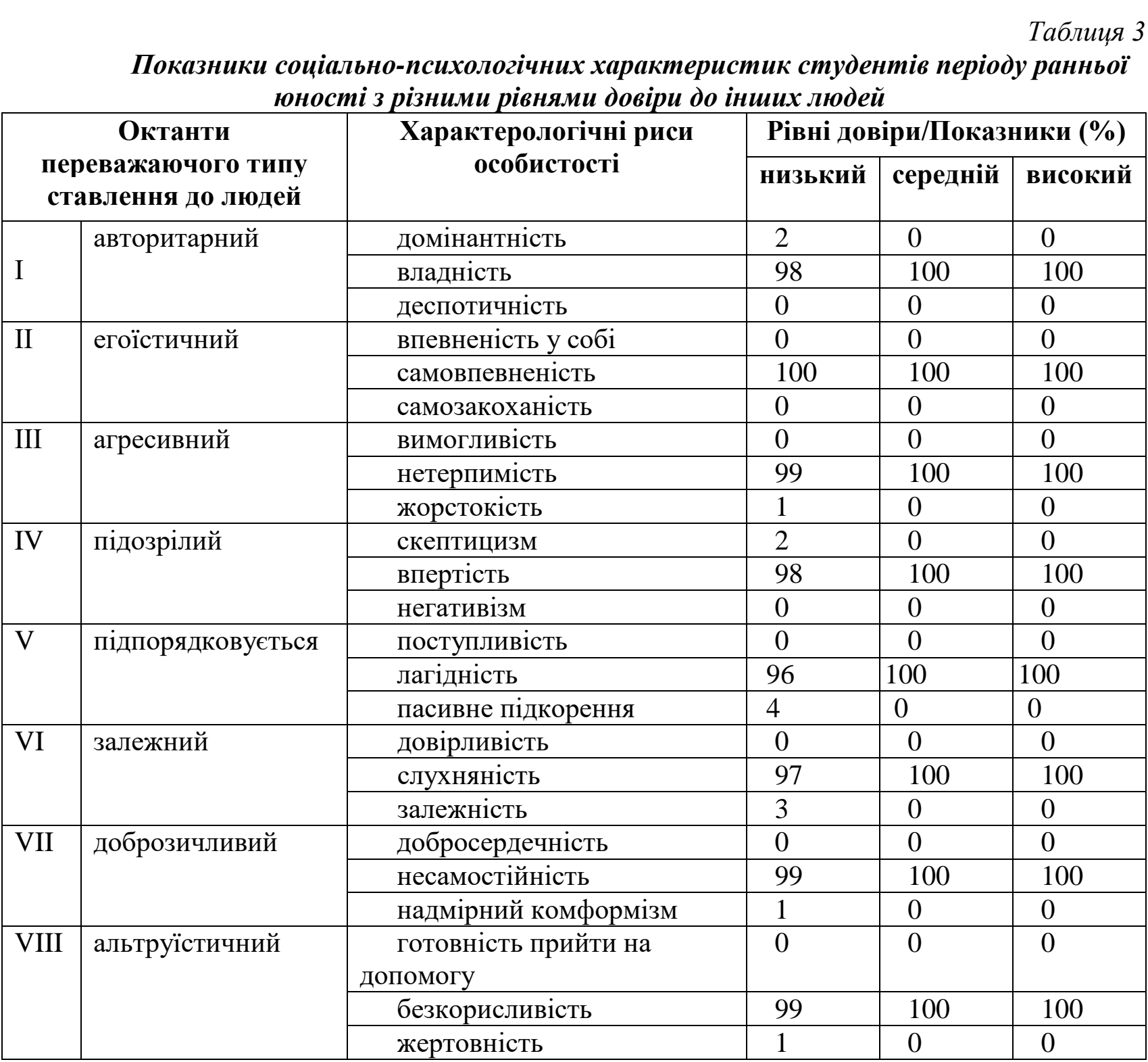

Такі суперечливі октанти у прояві переважаючого типу ставлення до людей свідчать про незрілість системи зрозумілих і стійких переконань юнаків і дівчат, про юнацький максималізм, категоричність оцінок, що вживаються з демонстративним скепсисом. Шляхом спроб та помилок відбувається успішне самовизначення, коли молоді люди отримують право придивитися до різних соціальних ролей, не віддаючи перевагу жодній з них, в результаті чого формуються важливі особистісні якості: усвідомленість, самостійність, незалежність. Рефлексія власного життєвого шляху, прагнення до самореалізації призводить до появи нових соціальних потреб: знайти своє місце серед інших, виділитися, бути особливим, грати певну роль в суспільстві. Виникає відповідальність не просто за себе, а за себе в спільній справі, за спільну справу і за інших людей.

Висновки i перспективи подальших розвідок. Результати проведеного емпіричного дослідження дозволили зробити висновки про те, що більшість студентів періоду ранньої юності виявляють низький рівень довіри до інших людей. Це зумовлює необхідність проведення психологічної роботи 3 метою підвищення рівня довіри та формування позитивного ставлення юнаків та дівчат до оточуючих людей.

Для розв’язання даної проблеми на базі Сарненського педагогічного коледжу нами розроблено та запропоновано такі методи та форми роботи із студентами $1-3$ курсів, а саме: комплекс тренінгових занять 3 формування вміння довіряти іншим людям та власних якостей, які сприяють виникненню довіри та забезпечення набуття досвіду їх практичного застосування в професійній діяльності майбутнього педагога. Нами розроблено тематичні Випуск 15, 2020. Збірник наукових праць РДгУ 
виховні години для роботи в академічних групах з даної проблематики. Таким чином, впровадження у систему фахової передвищої освіти шляхів виховання довірливого спілкування студентів у період ранньої юності дає можливість створити реальні передумови для формування компетентності особистісного самовдосконалення, формуванні психологічної грамотності, культури мислення та поведінки тощо.

\section{СПИСОК ПОСИЛАНЬ}

Антоненко, И. В. (2004). Доверие: сочиильно-психологический феномен. Москва: Социум. Диагностика уровня эмпатических способностей. Методика В. В.Бойко. (2020, март 20). Взято из https://pcenter.kiev.ua/test/empaticheskikh-sposobnostey/

Ефремкина, И. Н. (2019). Исследование особенностей социально-психологических характеристик у лиц юношеского возраста с различным уровнем доверия в межличностных отношениях. Вестник университета, 6, 191-197.

Ильин, Е. П. (2013). Психология доверия. Санкт-Петербург: Питер.

Корчакова, Н. В. (2018). Вікова тенеза просоиіальності особистості. (Дис. докт. психол. наук). Національний педагогічний університет імені М. П. Драгоманова, Київ.

Купрейченко, А. Б. (2008). Психология доверия и недоверия. Москва: Изд-во «Ин-т психологии РАН».

Мясищев, В. Н. (1998). О взаимосвязи общения, отношения и отражения как проблемы общей и социальной психологии. В Социально-психологические и лингвистические характеристики форм общения и развития контактов между людьми, Тезись симпозиума (с.128). Санкт-Петербург: Питер.

Скрипкина, Т. П. (1999). Взаимодоверие как основание межличностных взаимодействий. Вопросы психологии, 5, 21-30.

Сучасна освіта. Ключові компоненти компетентності вчителя. (2020, березень 20). Взято 3 https://osvita.ua/school/method/9170/

Тест міжособистісних відносин Лірі. (2020, березень 20). Взято 3: http://psychologis.com.ua/1-153.htm

Тест Шкала доверия М. Розенберга. Методика Вера в людей. Экспресс-диагностика. (2020, март 20). Взято из https://psycabi.net/testy/446-test-shkala-doveriya-m-rozenbergametodika-vera-v-lyudej-ekspress-diagnostika

Хьелл, Ю. Л. Теория личности. Санкт-Петербург: Питер, 2007.

\section{REFERENCES}

Antonenko, I. V. (2004). Doveriye: sotsialno-psikhologicheskiy fenomen [Trust: a sociopsychological phenomenon]. Moskva: Sotsium. 2004. [in Russian].

Diagnostika urovnya empaticheskikh sposobnostey. Metodika V. V. Boyko [Diagnostics of the level of empathic abilities. V.V. Boyko]. (2020, mart 20). Vzyato iz https://pcenter.kiev.ua/test/empaticheskikh-sposobnostey/. [in Russian].

Efremkina, I. N. (2019). Issledovaniye osobennostey sotsialno-psikhologicheskikh kharakteristik u lits yunosheskogo vozrasta $\mathrm{s}$ razlichnym urovnem doveriya $\mathrm{v}$ mezhlichnostnykh otnosheniyakh [A survey of the peculiarities of socio-psychological characteristics of adolescents with different levels of trust in interpersonal relationships]. Vestnik universiteta, 2019, 6, 191-197. [in Russian].

Ilin, E. P. (2013). Psikhologiya doveriya [The psychology of trust]. Sankt-Peterburg: Piter. [in Russian].

Korchakova, N. V. (2018) Vikova geneza prosotsialnosti osobystosti [Age genesis of prosocial personality.]. (Dys. dokt. psykhol. nauk). Natsionalnyi pedahohichnyi universytet imeni M. P. Drahomanova, Kyiv. [in Ukrainian].

Kupreychenko, A. B. (2008). Psikhologiya doveriya $i$ nedoveriya [The psychology of trust and distrust]. Moskva: Izd-vo «In-t psikhologii RAN». [in Russian].

Myasishchev, V. N. (1998). O vzaimosvyazi obshcheniya. otnosheniya i otrazheniya kak problemy obshchey i sotsialnoy psikhologii [About the relationship of communication, attitude and 
reflection as a problem of general and social psychology.]. V Sotsialno-psikhologicheskiye $i$ lingvisticheskiye kharakteristiki form obshcheniya i razvitiya kontaktov mezhdu lyudmi, Tezisy simpoziuma (s.128). Sankt-Peterburg: Piter. [in Russian].

Skripkina, T. P. (1999). Vzaimodoveriye kak osnovaniye mezhlichnostnykh vzaimodeystviy [Mutual trust as the basis of interpersonal interactions.]. Voprosy psikhologii, 5, 21-30. [in Russian].

Suchasna osvita. Kliuchovi komponenty kompetentnosti vchytelia [Key components of teacher competence]. (2020, berezen' 20). Vziato z: https://osvita.ua/school/method/9170/. [in Ukrainian].

Test mizhosobystisnykh vidnosyn Liri [Leary's interpersonal relationship test]. (2020, berezen' 20). Vziato z: http://psychologis.com.ua/-1-153.htm. [in Ukrainian].

Test Shkala doveriya M. Rozenberga. Metodika Vera v lyudey. Ekspress diagnostika [Test Scale of confidence by M. Rosenberg. Method Faith in people. Express diagnostics]. (2020, mart 20). Vzyato iz: https://psycabi.net/testy/446-test-shkala-doveriya-m-rozenberga-metodika-verav-lyudej-ekspress-diagnostika. [in Russian].

Khyell, L. (2007). Teoriya lichnosti [The theory of personality]. Sankt-Peterburg: Piter. [in Russian].

\title{
THE SURVEY OF FEATURES OF PSYCHOLOGICAL CHARACTERISTICS OF ADOLESCENTS WITH DIFFERENT LEVEL OF TRUST IN INTERPERSONAL RELATIONS
}

\author{
Olena Biletska \\ PhD student of Lifespan \& Pedagogical Psychology, \\ A teacher of Sarny Teachers' Training College \\ (Rivne State University of Humanities) \\ http://orcid.org/: ID 0000-0002-9447-4455 \\ DOI https://doi.org/10.35619/praprv.v1i15.179
}

\begin{abstract}
The article is devoted to the theoretical substantiation and empirical examination of the problem of trust and socio-psychological characteristics of adolescents (students). It was found that the level of empathy and trust of the individual and interpersonal relationships of young people are interrelated and characterized by a common psychological feature: the strength of empathy in the emotional sphere of personality and the ratio of levels of interpersonal relationships. Due to the peculiarities of empathy and trusting communication, young people can evaluate the people around them, establish a certain value of the relationship, acquired during some period of time. A radical change in the social situation of development causes the intensification of programs for finding personal self-realization ways, making responsible decisions, restructuring the system of relations with others. Social norms and rules, learned in previous age periods, form the basis for the formation of their own system of views on the realities of coexistence of people in society. Based on the results of the diagnosis, the vast majority of people $(85.7 \%)$ with a low level of trust in interpersonal relationships were identified, in which such sociopsychological characteristics as types of attitudes towards others and the level of empathic abilities were studied. The results of empirical research indicate the dependence of the personality in deciding whether or not to trust the opinion of others, the constant search for confirmation of the correctness of their choice, insecurity in their own abilities. Statistical analysis of the obtained results revealed some significant differences in styles (types) of interpersonal relationships, levels of development of empathic abilities of students with a low level of trust. The obtained results became a psychological basis for the development of socio-psychological training as an effective means of increasing the level of students'trust in early adolescence because it is trust that performs socio-psychological functions of cognition, interactivity, adaptation, integration, orientation, regulation, communication, forecasting, development, self-expression and self-improvement.
\end{abstract}

Key words: early adolescence, interpersonal relationships, trusting relationships, trust, empathy. 